\title{
Můžeme snížit riziko rekurentního infarktu myokardu?
}

Ve své přednášce v rámci 16. konference Interní medicína pro praxi, která proběhla on-line 30. dubna 2021, připomněla MUDr. Eva Kociánová kardioprotektivní význam kombinace $\beta$-blokátoru s ACE inhibitorem u pacientů po prodělaném infarktu myokardu a zdůraznila kompenzaci lipidemie, krevního tlaku a tepové frekvence k cílovým hodnotám nastaveným na základě stanovení velmi vysokého nebo extrémního kardiovaskulárního rizika u těchto pacientů. Poukázala na nízkou adherenci pacientů po IM k léčbě a potřebu opakované edukace a využití fixních kombinací léků pro její zvýšení, protože adherence k léčbě zásadním způsobem ovlivňuje prognózu těchto pacientů.

\section{Úvod}

Problematika sekundární prevence infarktu myokardu (IM) je velmi Široká. V ČR máme téměř 85000 pacientů po IM a podle údajư ÚZIS přibylo za rok 2018 pres 22000 nových.

Cílem sekundární prevence IM je zpomalení progrese aterosklerózy, snížení rizika trombózy na aterosklerotickém plátu, zamezení fibrotizace a remodelace ischemického ložiska, prevence opakování príhody a prodloužení života. Používáme k tomu pětici farmak: duální antiagregaci ticagrelorem + clopidogrelem, kyselinu acetylsalicylovou, statin, $\beta$-blokátor (BB) a ACE inhibitor (ACEI).

\section{Důkazy o prínosu BB a $A C E I$ u pacientů po infarktu myokardu}

U pacientů s kardiovaskulárním (KV) onemocněním je prítomna hyperaktivace sympatického nervového systému a systému renin-angiotenzin-aldosteron (RAAS). Oba mechanismy přispívají k nárůstu krevního tlaku a poškození cílových orgánů. Hyperaktivace těchto systémů se navzájem potencují (1-4). Proto je jejich duální blokáda cestou, jak tento patofyziologický proces přerušit. Podle aktuálních mezinárodních doporučených postupů (5-8) je vhodné podávat BB a ACEl u všech pacientů po non-STEMI (IM bez elevace úseku ST), u pacientů s chronickým koronárním syndromem, u pacientů s dysfunkcí levé komory po STEMI (IM s elevací úseku ST), u jedinců, kteří mají ischemickou chorobou srdeční (ICHS) a současně hypertenzi a u pacientů se srdečním selháním se sniženou ejekční frakcí (rEFHF). Prínos podávání ACEl a BB u těchto pacientů dokládá mimo jiné metaanalýza studie Brugts (9), zahrnující 11418 pacientů s ICHS, diabetem nebo cévní mozkovou príhodou (CMP) v anamnéze. Přidání ACEl perindoprilu k BB bylo u těchto pacientů spojeno se snižením rizika složeného sledovaného parametru zahrnujícího KV mortalitu, nefatální IM a nefatální CMP o 20\%. Riziko IM kleslo o $23 \%$ a celková mortalita o 22\%.

Diskutovanou otázkou je podávání BB po IM bez př́tomnosti dysfunkce levé komory. Přestože se doporučení mění, v reálné klinické praxi se u těchto pacientů BB predepisují a tento postup je v souladu s výsledky metaanalýzy 7 studií (10), která prokázala snížení celkové mortality o 21 \% u pacientů po STEMI se zachovanou ejekční frakcí prì léčbě BB. Bisoprolol disponuje dlouhodobými daty, které dokládají významné snížení celkové mortality v porovnání s ostatními BB (nebivolol, metoprolol) v horizontu až 15 let (Obr. 1) (11).

Obr. 1. Významně nižší mortalita při dlouhodobé léčbě bisoprololem v porovnání s ostatními BB (11)

Longitudinální mortalita: poměr rizik (HR) a 95\% interval spolehlivosti $(95 \% \mathrm{Cl})$ při léčbě bisoprololem v porovnání s ostatními $\beta$-blokátory (BB)

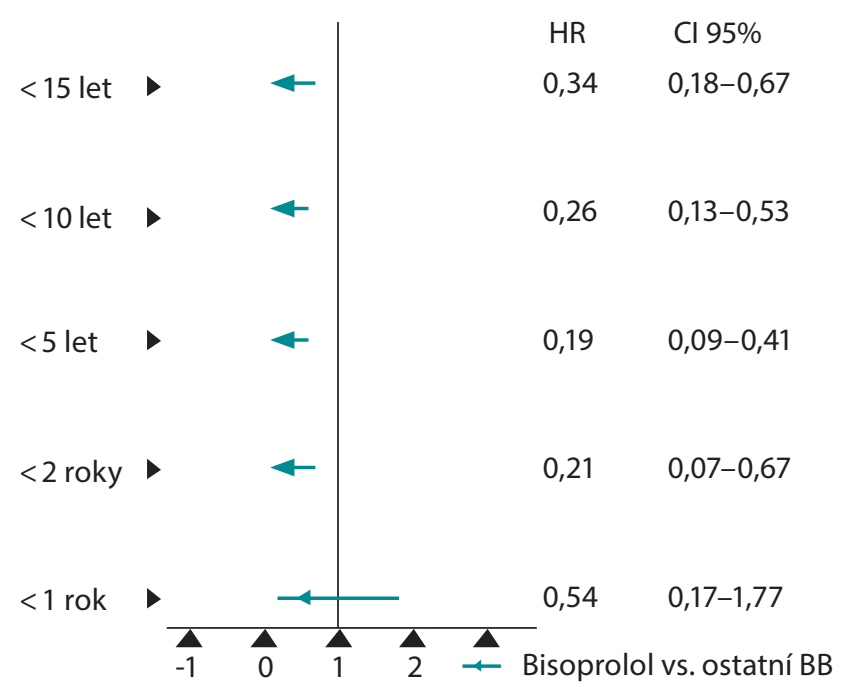

Porovnání kombinace BB + ACEI s BB + AT, blokátor (sartan) u pacientů po non-STEMI ukázalo významně větší snížení celkové i KV mortality ve skupině s ACEI (12). ACEl mají prokázané kardioprotektivní účinky, přičemž velký objem důkazů je k dispozici u perindoprilu. Metaanalýza 20 studií zahrnujících pacienty s hypertenzí ukázala po mediánu sledování 4,3 roku snížení celkové mortality při léčbě perindoprilem o 13\% (13). Ve studii s vysoce rizikovými pacienty snížil perindopril riziko IM o 28\% (14) a u pacientů po akutním koronárním syndromu (AKS) snížil tento ACEI 5letou mortalitu o $30 \%$ (15).

\section{Role adherence $\mathrm{k}$ léčbě u recidivujících AKS}

Je známo, že značná část pacientů nedodržuje předepsanou preventivní KV léčbu a podle odhadů Ize v Evropě přičíst asi $9 \%$ všech KV 
příhod právě této non-adherenci (6). Tuto situaci ilustruje následující prípad pacienta.

\section{Kazuistika}

Na kontrolu do ordinace internisty přichází muž narozený v roce 1949, který před 4 měsíci prodělal AKS. Subjektivně nemá žádné potíže, uvádí, že léky užívá pravidelně, ale nepamatuje si názvy ani počet tablet. Kouření omezil pouze částečně, pohybovou aktivitu nerozšíril a od propuštění z nemocnice přibral 2 kg (tělesná hmotnost 97 kg). Má nekompenzovanou hypertenzi (142/88 mm Hg), tachykardii (92/min) a hladina LDL cholesterolu (po nasazení statinu) u něj vzrostla z hodnoty 3,1 mmol/l při propuštění z nemocnice na 3,2 mmol/l. Tyto výsledky vzbuzují dojem non-adherence pacienta k predepsané farmakoterapii.

Taková situace není neobvyklá. Bylo zjištěno, že první 4 měsíce po IM nedodržuje léčbu $22 \%$ pacientů a 2 roky po IM dokonce $64 \%$ pacientů (16). Non-adherence ke KV preventivní léčbě je přitom spojena se zvýšením celkové mortality o 74 \% a rizika koronární revaskularizace o 32 \% (17). Nedodržování léčby ACEl Ize přičíst zvýšení celkové mortality o $74 \%$ a nedodržování léčby BB o 50 \% (17). Pacienti po IM ale často nedodržují ani další doporučené farmakologické a nefarmakologické postupy. Studie, která hodnotila dosažení 6 cílových parametrů sekundární KV prevence (LDL cholesterol < 1,8 mmol/I, STK < $140 \mathrm{~mm}$ $\mathrm{Hg}$, normoglykemie, pravidelná fyzická aktivita, zanechání kouření a adherence $\mathrm{k}$ farmakoterapii statinem, BB a ACEI), ukázala, že po 2 letech splnilo všech 6 cílů pouze 3,5 \% pacientů. U 46\% pacientů došlo k recidivě velké $\mathrm{KV}$ příhody (18).

Non-adherence k léčbě má vždy svoji míru, a proto byl stanoven práh tzv. škodlivé non-adherence, kterou Ize definovat jako < $80 \%$ dní krytých lékem.

\section{Kde máme rezervy v sekundární prevenci po IM}

Prvním z piliřru správné sekundární KV prevence je dobře stanovené KV riziko pacientů po IM. Asi $80 \%$ pacientů po AKS má velmi vysoké KV riziko, u zbývajících $20 \%$ pacientů jde ovšem o extrémní KV riziko. Jedná se o jedince:

- s prededchozí vaskulární príhodou v posledních 2 letech,

- s víceetážovou aterosklerózou (v koronárních tepnách, periferních tepnách, karotických tepnách)

- s doloženým postižením více koronárních tepen,

- s familiární hypercholesterolemií,

- s diabetem + dalším rizikovým faktorem (zvýšení HsCRP > 3, lipoproteinu a $>50 \mathrm{mg} / \mathrm{lc} i \mathrm{eGFR}<60 \mathrm{ml} / \mathrm{min}$ )

- se SCORE $>20 \%$ (5)

Tyto pacienty je třeba vyhledávat a snažit se u nich dosáhnout př́snější cílů.

Druhým pilǐrem je kompenzace hypertenze. Prưzkum provedený v ČR v roce 2018 ukázal, že hypertenzi má 91,9\% pacientů s ICHS (19). Podle výsledků studie EUROASPIRE V nemá v ČR kompenzovaný krevní tlak 60\% pacientů s IM v anamnéze. Podle nových doporučení je navíc vhodné zvážit antihypertenzní léčbu i u pacientů s ICHS s vysokým normálním krevním tlakem (130-139/85-89 mm Hg).
Třetím pilî̌em sekundární KV prevence je kontrola tepové frekvence (TF) pacientů po IM. Zvýšení TF o 20/min zvyšuje riziko úmrtí z KV prríčin zhruba o 40\%, což je stejný nárůst jako při zvýšení krevního tlaku o 15-20 mm Hg (20, 21). Vysoké riziko KV úmrtí mají zejména pacienti po IM s TF $>80 / \mathrm{min}$

Rezervu při zvýšení adherence k farmakoterapii po IM máme jistě v používání fixních kombinací. Tito pacienti užívají průměrně 6,3 tablety denně (19), což zvyšuje pravděpodobnost non-adherence. Podle doporučení ESC pro léčbu hypertenze z roku 2018 je užívání více než 5 tablet denně spojeno s rizikem velmi vysoké až úplné non-adherence. Fixní kombinace 2 účinných látek v 1 tabletě umožňuje lepší dodržování léčby. Podle nedávné studie zlepšují fixní kombinace adherenci o 54\% a prostřednictvím zvýšení adherence zlepšují také prognózu pacientů (23).

Práce provedená na LF v Olomouci ukázala, že non-adherence k léčbě BB nebo fixní kombinací obsahující BB se dá dobře rozpoznat podle TF. Jako hraniční byla určena hodnota TF 75,5/min. Bylo zjištěno, že hodnota TF $>75,5 /$ min ukazuje se specificitou $86,8 \%$ a senzitivitou $62,6 \%$, že pacient neuživá předepsaný BB (Obr. 2) (24).TF je nutné při každém vyšetření pacienta měřit. Nejlépe u sedícího pacienta nejméně po 5 minutách v klidu, po změření krevního tlaku. Odečet má probíhat minimálně po dobu 30 s a může ho provádět zdravotní sestra. Při vysoké TF je třeba hned reagovat titrací dávky BB, u nemocných se srdečním selháním Ize využít i ivabradin.

Obr. 2. Tepová frekvence $>75,5 /$ min prìi léčbě BB svědčí pro non-adherenci (24)

Celkem $(\mathrm{N}=220)$ AUC $=0,802, p<0,001$

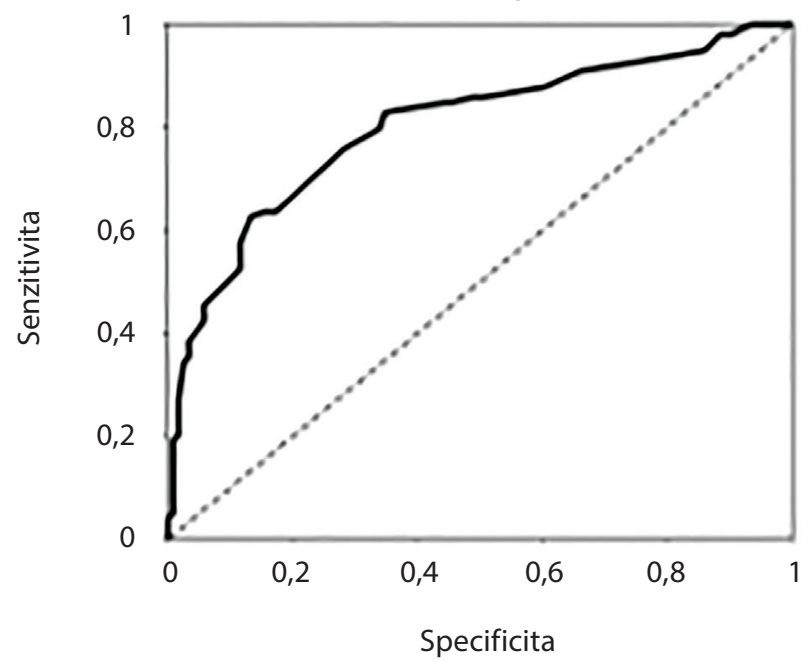

$A \cup C=$ plocha pod krivkou

\section{Praktický návod pro sekundární prevenci u pacientů po IM}

Pacienty po IM je třeba vést k dodržování režimových opatření zahrnujících asistovanou redukci tělesné hmotnosti, zanechání kouření a udržení normoglykemie. U každého pacienta by mělo být stanoveno KV riziko, tj. velmi vysoké vs. extrémní, protože cílové hodnoty léčby se u těchto skupin nemocných liší. U všech pacientů po IM je doporučen statin v maximální dávce, prípadně ezetimib a PCSK-9 inhibitor pro dosažení cílových hodnot lipidového profilu. Nutné je řešit prípadnou statinovou intoleranci. Lipidový profil má být vyšetřen každých 3-6 týdnů a v prípadě neuspokojivých hodnot je třeba promptně intenzifikovat hypolipidemickou léčbu k cílovým 


\section{ZAZNĚLO NA 16. KONFERENCI INTERNÍ MEDICÍNA PRO PRAXI}

MŮŽEME SNIIZIT RIZIKO REKURENTNIIHO INFARKTU MYOKARDU?

hodnotám. Ty činí u pacientů s velmi vysokým KV rizikem u LDL cholesterolu $<1,4 \mathrm{mmol} / \mathrm{I}$ + pokles nejméně o $50 \%$, u triglyceridů $<1,5 \mathrm{mmol} / \mathrm{l}$, u apoB $<65 \mathrm{mg} / \mathrm{dl}$ a u non-HDL cholesterolu $<2,2 \mathrm{mmol} / \mathrm{I}$. V prípadě pacientů s extrémním KV rizikem jsou cílové hodnoty LDL cholesterolu $<1$ mmol// + pokles nejméně o $50 \%$, triglyceridů $<1,5 \mathrm{mmol} / \mathrm{l}$, apoB $<55 \mathrm{mg} / \mathrm{dl}$ a non-HDL cholesterolu <1,8 mmol/I. Dále je nezbytné u pacientů po IM kompenzovat krevní tlak. Základní antihypertenzní léčbou je ACEl + BB, přičemž po 2 měsících by mělo být provedeno ambulantní nebo domácí monitorování krevního tlaku (APBM/HPBM). Cílovou hodnotou je 120-130/70-80 mm Hg. Pokud není této hodnoty krevního tlaku dosaženo, je třeba prídat k antihypertenzní léčbě blokátor Ca kanálu nebo thiazidové diuretikum, opět po 2 měsících provést ABPM/HBPM a léčbu prípadně dále intenzifikovat. Dosažení kompenzace TK je klíčové, proto je při neúspěchu antihypertenzní léčby nutné vyloučit sekundární príčinu hypertenze a prípadně přidat k léčbě spironolakton nebo doxazosin (Obr. 3) (25).

\section{Závěr}

Cílem sekundární prevence u pacientů po IM je snížení jejich KV rizika, prevence recidivy koronární príhody a snaha o prodloužení života. Kombinace ACEI + BB je u této populace kardioprotektivní. U pacientů se sníženou ejekční frakcí levé komory (i asymptomatických) snižuje mortalitu

Obr. 3. Praktický návod pro sekundární prevenci pacientů po IM (25)

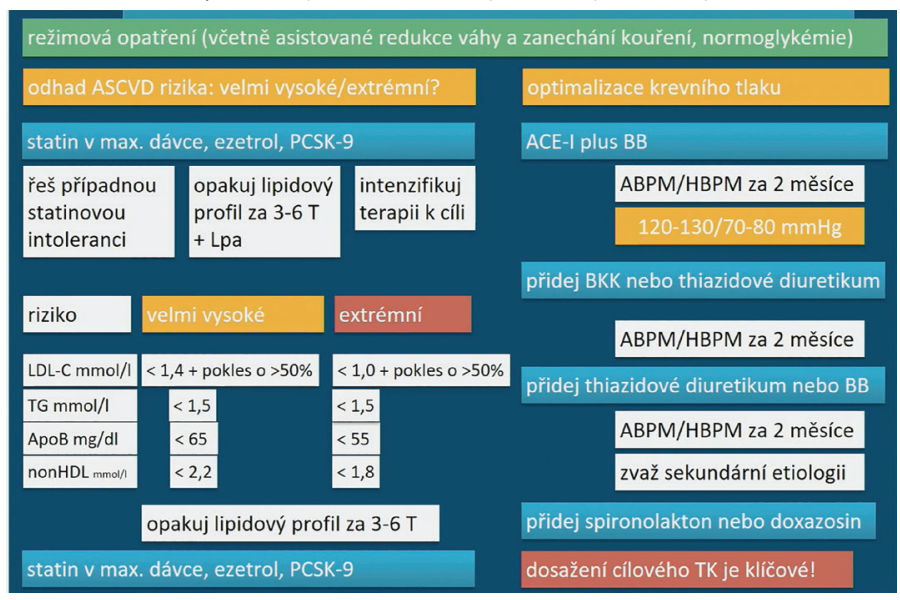

o $23 \%$ a u pacientů se zachovanou ejekční frakcí působí proti remodelaci levé komory a rozvoji srdečního selhání. Je třeba mít na paměti, že již 6 měsíců po prodělaném IM neužívá polovina pacientů predepsanou medikaci vůbec, nebo ji uživá jen částečně. Základem udržení spolupráce pacienta je opakovaná edukace a co největší zjednodušení léčebného schématu s použitím fixních kombinací.

Připravila MUDr. Zuzana Zafarová

\section{LITERATURA}

1. Rosendorff C, Lackland DT, Allison M, Aronow WS, Black HR, Blumenthal RS, Cannon CP, de Lemos JA, Elliott WJ, Findeiss L, Gersh BJ, Gore JM, Levy D, Long JB, O'Connor CM, O'Gara PT, Ogedegbe G, Oparil S, White WB; American Heart Association, American College of Cardiology, and American Society of Hypertension. Treatment of hypertension in patients with coronary artery disease: a scientific statement from the American Heart Association, American College of Cardiology, and American Society of Hypertension. Hypertension. 2015; 65(6): 1372-1407. 2. Dzau VJ, Antman EM, Black HR, Hayes DL, Manson JE, Plutzky J, Popma JJ, Stevenson W. The cardiovascular disease continuum validated: clinical evidence of improved patient outcomes: part I: Pathophysiology and clinical trial evidence (risk factors through stable coronary artery disease). Circulation. 2006; 114(25): 2850-2870.

3. Abraham WT, Greenberg BH, Yancy CW. Pharmacologic therapies across the continuum of left ventricular dysfunction. Am J Cardiol. 2008; 102(5A): 21G-28G.

4. de Champlain J, Karas M, Toal C, Nadeau R, Larochelle P. Effects of antihypertensive therapies on the sympathetic nervous system. Can J Cardiol. 1999; 15 Suppl A: 8A-14A.

5. Knuuti J, Wijns W, Saraste A, Capodanno D, Barbato E, Funck-Brentano C, Prescott E, Storey RF, Deaton C, Cuisset T, Agewall S, Dickstein K, Edvardsen T, Escaned J, Gersh BJ, Svitil P, Gilard M, Hasdai D, Hatala R, Mahfoud F, Masip J, Muneretto C, Valgimigli M, Achenbach S, Bax Jj; ESC Scientific Document Group. 2019 ESC Guidelines for the diagnosis and management of chronic coronary syndromes. Eur Heart J. 2020; 41(3): 407-477.

6. Collet JP, Thiele H, Barbato E, Barthélémy O, Bauersachs J, Bhatt DL, Dendale P, Dorobantu M, Edvardsen T, Folliguet T, Gale CP, Gilard M, Jobs A, Jüni P, Lambrinou E, Lewis BS, Mehilli J, Meliga E, Merkely B, Mueller C, Roffi M, Rutten FH, Sibbing D, Siontis GCM; ESC Scientific Document Group. 2020 ESC Guidelines for the management of acute coronary syndromes in patients presenting without persistent ST-segment elevation. Eur Heart J. 2021; 42(14): 1289-1367. 7. Ibanez B, James S, Agewall S, Antunes MJ, Bucciarelli-Ducci C, Bueno H, Caforio ALP, Crea F, Goudevenos JA, Halvorsen S, Hindricks G, Kastrati A, Lenzen MJ, Prescott E, Roffi M, Valgimigli M, Varenhorst C, Vranckx P, Widimský P; ESC Scientific Document Group. 2017 ESC Guidelines for the management of acute myocardial infarction in patients presenting with ST-segment elevation: The Task Force for the management of acute myocardial infarction in patients presenting with ST-segment elevation of the European Society of Cardiology (ESC). Eur Heart J. 2018; 39(2): 119-177.

8. Rosendorff C, Lackland DT, Allison M, Aronow WS, Black HR, Blumenthal RS, Cannon CP, de Lemos JA, Elliott WJ, Findeiss L, Gersh BJ, Gore JM, Levy D, Long JB, O'Connor CM, O'Gara PT, Ogedegbe G, Oparil S, White WB; American Heart Association, American College of Cardiology, and American Society of Hypertension. Treatment of hypertension in patients with coronary artery disease: a scientific statement from the American Heart Association, American College of Cardiology, and American Society of Hypertension. Hypertension. 2015; 65(6): 1372-1407. 9. Brugts JJ, Bertrand M, Remme W, Ferrari R, Fox K, MacMahon S, Chalmers J, Simoons ML, Boersma E. The Treatment Effect of an ACE-Inhibitor Based Regimen with Perindopril in Relation to Beta-Blocker use in 29,463 Patients with Vascular Disease: a Combined Analysis of Individual
Data of ADVANCE, EUROPA and PROGRESS Trials. Cardiovasc Drugs Ther. 2017; 31(4): 391-400 10. Misumida N, Harjai K, Kernis S, Kanei Y. Does Oral Beta-Blocker Therapy Improve Long-Term Survival in ST-Segment Elevation Myocardial Infarction With Preserved Systolic Function? A Meta-Analysis. J Cardiovasc Pharmacol Ther. 2016; 21(3): 280-285.

11. Sabidó M, Hohenberger T, Grassi G. Pharmacological intervention in hypertension using beta-blockers: Real-world evidence for long-term effectiveness. Pharmacol Res. 2018; 130: 191-197. 12. Kim YH, Her AY, Jeong MH, Kim BK, Lee SY, Hong SJ, Shin DH, Kim JS, Ko YG, Choi D, Hong MK, Jang Y. Comparison Between Beta-Blockers with Angiotensin-Converting Enzyme Inhibitors and Beta-Blockers with Angiotensin II Type I Receptor Blockers in ST-Segment Elevation Myocardial Infarction After Successful Percutaneous Coronary Intervention with Drug-Eluting Stents. Cardiovasc Drugs Ther. 2019; 33(1): 55-67.

13. van Vark LC, Bertrand M, Akkerhuis KM, Brugts JJ, Fox K, Mourad JJ, Boersma E. Angiotensin-converting enzyme inhibitors reduce mortality in hypertension: a meta-analysis of randomized clinical trials of renin-angiotensin-aldosterone system inhibitors involving 158,998 patients. Eur Heart J. 2012; 33(16): 2088-2097.

14. Savarese G, Costanzo P, Cleland JG, Vassallo E, Ruggiero D, Rosano G, Perrone-Filardi P. A meta-analysis reporting effects of angiotensin-converting enzyme inhibitors and angiotensin receptor blockers in patients without heart failure. J Am Coll Cardiol. 2013; 61(2): 131-42.

15. Hara M, Sakata Y, Nakatani D, Suna S, Usami M, Matsumoto S, Sugitani T, Nishino M, Sato H, Kitamura T, Nanto S, Hamasaki T, Hori M, Komuro I; OACIS Investigators. Comparison of 5-year survival after acute myocardial infarction using angiotensin-converting enzyme inhibitor versus angiotensin II receptor blocker. Am J Cardiol. 2014; 114(1): 1-8.

16. Akincigil A, Bowblis JR, Levin C, Jan S, Patel M, Crystal S. Long-term adherence to evidence based secondary prevention therapies after acute myocardial infarction. J Gen Intern Med. 2008; 23(2): 115-121.

17. Ho PM et al. Medication nonadherence is associated with a broad range of adverse outcomes in patients with coronary artery diseaseAm Heart J. 2008; 155: 772-779.

18. Ergatoudes C, Thunström E, Rosengren A, Björck L, Bengtsson Boström K, Falk K, Fu M Long-term secondary prevention of acute myocardial infarction (SEPAT) - guidelines adherence and outcome. BMC Cardiovasc Disord. 2016; 16(1): 226.

19. Hradec J. Klinické charakteristiky a farmakoterapie nemocných s chronickou ICHS v ČR $\checkmark$ roce 2018 - výsledky průřezového průzkumu. Medicína po promoci. 3/2019; 20: 225-232. 20. Bangalore S, Messerli FH, Ou FS, Tamis-Holland J, Palazzo A, Roe MT, Hong MK, Peterson ED; CRUSADE Investigators. The association of admission heart rate and in-hospital cardiovascular events in patients with non-ST-segment elevation acute coronary syndromes: results from 135164 patients in the CRUSADE quality improvement initiative. Eur Heart J. 2010; 31(5): 552-560.

21. Tavazzi L. Heart rate as a therapeutic target in heart failure? Eur Heart J. 2003 (Suppl G); 5: G15-G18. 
MŮŽEME SNIZZIT RIZIKO REKURENTNÍHO INFARKTU MYOKARDU?

22. Williams B, Mancia G, Spiering W, Agabiti Rosei E, Azizi M, Burnier M, Clement DL, Coca A de Simone G, Dominiczak A, Kahan T, Mahfoud F, Redon J, Ruilope L, Zanchetti A, Kerins M, Kjeldsen SE, Kreutz R, Laurent S, Lip GYH, McManus R, Narkiewicz K, Ruschitzka F, Schmieder RE, Shlyakhto E, Tsioufis C, Aboyans V, Desormais I; ESC Scientific Document Group. 2018 ESC/ESH Guidelines for the management of arterial hypertension. Eur Heart J. 2018; 39(33): 3021-3104 23. Simons LA, Chung E, Ortiz M. Long-term persistence with single-pill, fixed-dose combination therapy versus two pills of amlodipine and perindopril for hypertension: Australian experience. Curr Med Res Opin 2017; 33(10): 1783-1787.

24. Kociánová E, Václavík J, Tomková J, Ondra P, Jarkovský J, Benešová K, Václavík T, Kamasová $M$, Táborský $M$. Heart rate is a useful marker of adherence to beta-blocker treatment in hypertension. Blood Press 2017; 26(5): 311-318.

25. Unger T, Borghi C, Charchar F, Khan NA, Poulter NR, Prabhakaran D, Ramirez A, Schlaich M, Stergiou GS, Tomaszewski M, Wainford RD, Williams B, Schutte AE. 2020 International Society of Hypertension Global Hypertension Practice Guidelines. Hypertension 2020; 75(6): 1334-1357. 